\title{
Front Matter: Volume 6998
}

, "Front Matter: Volume 6998," Proc. SPIE 6998, Solid State Lasers and Amplifiers III, 699801 (12 May 2008); doi: 10.1117/12.802144

SPIE. Event: SPIE Photonics Europe, 2008, Strasbourg, France 


\title{
PROCEEDINGS OF SPIE
}

\section{Solid State Lasers and Amplifiers III}

\author{
Jonathan A. Terry \\ Thomas Graf \\ Helena Jelínková \\ Editors
}

\section{8-10 April 2008 \\ Strasbourg, France}

Sponsored by

SPIE Europe

Cosponsored by

Alsace International (France)

Conseil Général du Bas-Rhin (France)

Région Alsace (France)

Communauté Urbaine de Strasbourg (France)

Cooperating Organizations

AFOP-Association Française des Industries de l'Optique et de la Photonique (France) • EOSEuropean Optical Society (Germany) - EPIC-European Photonics Industry Consortium (France) ePIXnet (Belgium) • IOP_Institute of Physics (United Kingdom) - NEMO—Network of Excellence on Micro-Optics (Belgium) • OLAS (Italy) • The OLLA Project (Germany) • OPERA 2015 (Belgium) • PhOREMOST (Ireland) • Photonics Knowledge Transfer Network (United Kingdom) • Photonics Cluster (United Kingdom) • Photonics4Life (Germany) • Photonics 21 (Germany) • RhenaPhotonics Alsace (France)

Published by

SPIE

Volume 6998 
The papers included in this volume were part of the technical conference cited on the cover and title page. Papers were selected and subject to review by the editors and conference program committee. Some conference presentations may not be available for publication. The papers published in these proceedings reflect the work and thoughts of the authors and are published herein as submitted. The publisher is not responsible for the validity of the information or for any outcomes resulting from reliance thereon.

Please use the following format to cite material from this book:

Author(s), "Title of Paper," in Solid State Lasers and Amplifiers III, edited by Jonathan A. Terry, Thomas Graf, Helena Jellnkov; Proceedings of SPIE Vol. 6998 (SPIE, Bellingham, WA, 2008) Article CID Number.

ISSN 0277-786X

ISBN 9780819471963

Published by

SPIE

P.O. Box 10, Bellingham, Washington 98227-0010 USA

Telephone +1 3606763290 (Pacific Time) · Fax +1 3606471445

SPIE.org

Copyright (C 2008, Society of Photo-Optical Instrumentation Engineers

Copying of material in this book for internal or personal use, or for the internal or personal use of specific clients, beyond the fair use provisions granted by the U.S. Copyright Law is authorized by SPIE subject to payment of copying fees. The Transactional Reporting Service base fee for this volume is $\$ 18.00$ per article (or portion thereof), which should be paid directly to the Copyright Clearance Center (CCC), 222 Rosewood Drive, Danvers, MA 01923. Payment may also be made electronically through CCC Online at copyright.com. Other copying for republication, resale, advertising or promotion, or any form of systematic or multiple reproduction of any material in this book is prohibited except with permission in writing from the publisher. The CCC fee code is $0277-786 \mathrm{X} / 08 / \$ 18.00$.

Printed in the United States of America.

Publication of record for individual papers is online in the SPIE Digital Library.

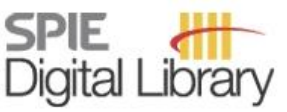

SPIEDigitallibrary.org

Paper Numbering: Proceedings of SPIE follow an e-First publication model, with papers published first online and then in print and on CD-ROM. Papers are published as they are submitted and meet publication criteria. A unique, consistent, permanent citation identifier (CID) number is assigned to each article at the time of the first publication. Utilization of CIDs allows articles to be fully citable as soon they are published online, and connects the same identifier to all online, print, and electronic versions of the publication. SPIE uses a six-digit CID article numbering system in which:

- The first four digits correspond to the SPIE volume number.

- The last two digits indicate publication order within the volume using a Base 36 numbering system employing both numerals and letters. These two-number sets start with 00, 01, 02, 03, 04, 05, 06, 07, 08, 09, OA, OB ... OZ, followed by 10-1Z, 20-2Z, etc.

The CID number appears on each page of the manuscript. The complete citation is used on the first page, and an abbreviated version on subsequent pages. Numbers in the index correspond to the last two digits of the six-digit CID number. 


\section{Contents}

ix Conference Committee

xi Introduction

\section{SESSION 1 FIBRE LASERS}

699803 8-ns Q-switched fiber laser using resonant saturable absorber mirror [6998-02]

T. Hakulinen, O. G. Okhotnikov, Tampere Univ. of Technology (Finland)

$699804 \mathrm{CW}$-operation of an Ytterbium doped 19-core fiber laser [6998-03]

A. Popp, M. Abdou Ahmed, D. Kauffmann, A. Voss, T. Graf, Univ. Stuttgart (Germany)

699805 Soliton crystal fiber laser [6998-04]

A. Haboucha, A. Komarov, M. Salhi, H. Leblond, F. Sanchez, Lab. POMA FRE, Univ. d'Angers (France)

699807 High power shortwave infrared fibre lasers that use silica host material (Invited Paper)

[6998-06]

S. D. Jackson, Univ. of Sydney (Australia)

699809 Mode-locked Yb-doped large-mode-area microstructure fiber laser [6998-08]

C. Lecaplain, A. Hideur, C. Chédot, G. Martel, Univ. de Roven (France); B. Ortaç, J. Limpert, Friedrich-Schiller-Univ. Jena (Germany)

6998 OA Improvement of $\mathrm{Yb}^{3+}$ doped optical fiber preforms by using MCVD method [6998-09]

V. Petit, E. H. Sekiya, T. Okazaki, R. Bacus, P. Barua, Toyota Technological Institute (Japan);

B. Yao, K. Ohsono, Hitachi Cable (Japan); K. Saito, Toyota Technological Institute (Japan)

\section{SESSION 2 PULSED SSL}

6998 OB Compact and efficient mode-locked lasers based on QD-SESAMs (Invited Paper) [6998-10] E. U. Rafailov, Univ. of Dundee (United Kingdom); A. A. Lagatsky, Univ. of St. Andrews (United Kingdom); S. A. Zolotovskaya, Univ. of Dundee (United Kingdom); W. Sibbett, Univ. of St. Andrews (United Kingdom)

6998 OC Efficient, high peak power, Q-switched, tunable, diode pumped Tm:YLF laser [6998-11] J. K. Jabczyński, L. Gorajek, W. Zendzian, J. Kwiatkowski, Military Univ. of Technology (Poland); H. Jelinkova, J. Sulc, M. Nemec, Czech Technical Univ. (Czech Republic)

6998 OD Q-switching a fiber laser with a dual mode single crystal photo-elastic modulator [6998-12] F. Bammer, Vienna Univ. of Technology (Austria); R. Petkovsek, Univ. of Ljubljana (Slovenia); D. Schuöcker, Vienna Univ. of Technology (Austria); J. Mozina, Univ. of Ljubljana (Slovenia) 
6998 OE High-energy diode-pumped Yb:YAG chirped pulse amplifier [6998-13]

M. Siebold, Max-Planck-Institute for Quantum Optics (Germany) and Friedrich-Schiller-Univ. Jena (Germany); C. Wandt, S. Klingebiel, Z. Major, S. Trushin, I. Ahmad, T.-J. Wang, MaxPlanck-Institute for Quantum Optics (Germany); J. Hein, Friedrich-Schiller-Univ. Jena (Germany); F. Krausz, S. Karsch, Max-Planck-Institute for Quantum Optics (Germany)

6998 OF Impact of pumping configuration on all-fibered femtosecond chirped pulse amplification [6998-14]

J.-B. Lecourt, C. Duterte, A. Bertrand, F. Liégeois, Y. Hernandez, D. Giannone, Multitel

(Belgium)

6998 OG Q-switched high-power disk laser [6998-15]

Y. Chivel, I. Niconchuk, D. Zatiagin, Stepanov Institute of Physics (Belarus)

\section{SESSION $3 \quad$ BEAM CONTROL AND TRANSMISSION}

$6998 \mathrm{OH} \quad$ Radially polarized Yb:YAG thin-disc laser (Invited Paper) [6998-16]

M. Abdou Ahmed, M. M. Vogel, A. Austerschulte, F. Sterns, A. Voss, T. Schoder, M. Ubl, Univ. Stuttgart (Germany); M. Pritschow, Institut für Mikroelektronik Stuttgart (Germany); T. Graf, Univ. Stuttgart (Germany)

6998 Ol 3-dimensional simulation of solid state lasers [6998-17] M. Wohlmuth, C. Pflaum, Univ. of Erlangen-Nuremberg (Germany)

$69980 \mathrm{~J}$ Detection of mode conversion effects in passive LMA fibers by means of optical correlation analysis [6998-22]

T. Kaiser, B. Lüdge, Univ. Jena (Germany); S. Schröter, Institut für Photonische Technologien (Germany); D. Kauffmann, Univ. Stuttgart (Germany); M. Duparré, Univ. Jena (Germany)

6998 OK Full vectorial finite-element simulations of Bragg fibers for single-mode beam delivery systems [6998-19]

M. M. Vogel, M. Abdou-Ahmed, A. Voß, D. Kauffmann, T. Graf, Univ. Stuttgart (Germany)

6998 OL Efficient linear-to-radial polarization converter for high-power lasers [6998-20]

G. Machavariani, S. Jackel, Y. Lumer, I. Moshe, A. Meir, Soreq Nuclear Research Ctr. (Israel)

$69980 \mathrm{M}$ Investigation of bending effects on evanescent-field coupled waveguides designed for high-power fundamental-mode delivery systems [6998-21]

D. Kauffmann, M. Abdou Ahmed, F. Kizhakeparampil, T. Rataj, M. M. Vogel, A. Popp,

A. Voß, T. Graf, Univ. Stuttgart (Germany)

6998 ON Transverse mode analysis of a laser beam with a non-optical technique [6998-18]

R. de Saint Denis, M. Fromager, F. Porée, K. Ait-Ameur, ENSICAEN-CEA-UCBN (France)

$699800 \quad$ Novel coupling device of high peak power pulsed laser to multimode fiber [6998-23] X. Zhao, Y. Gao, W. Cheng, Y. Cheng, W. Su, China Academy of Engineering Physics (China) 
6998 OP Some new approaches for development of mid-IR laser sources (Invited Paper) [6998-24]

T. T. Basiev, M. E. Doroshenko, L. I. Ivleva, V. V. Osiko, General Physics Institute (Russia);

V. V. Badikov, D. V. Badikov, Kuban State Univ. (Russia)

$69980 Q \quad 2$ watt $2 \mu \mathrm{m} \mathrm{Tm} /$ Ho fiber laser system passively Q-switched by antimonide semiconductor saturable absorber [6998-25]

S. Kivistö, T. Hakulinen, M. Guina, Tampere Univ. of Technology (Finland); K. Rößner, A. Forchel, Univ. Würzburg (Germany); O. Okhotnikov, Tampere Univ. of Technology (Finland)

6998 OR Laser action in bulk Cr:ZnSe crystals [6998-26]

P. Koranda, H. Jelínková, M. Němec, J. Šulc, Czech Technical Univ. (Czech Republic); M. E. Doroshenko, T. T. Basiev, General Physics Institute (Russia); V. K. Komar,

A. S. Gerasimenko, V. M. Puzikov, Institute for Single Crystals (Ukraine); V. V. Badikov,

D. V. Badikov, Kuban State Univ. (Russia)

6998 OS Effects of pulse timing parameters on bulk erbium laser operation in the eyesafe region [6998-27]

E. Georgiou, N. Lazarides, Technological Educational Institute of Crete (Greece);

O. Musset, J. P. Boquillon, Institut Carnot de l'Univ. de Bourgogne (France)

6998 OT Tm-doped vanadates under pulsed pumping with variable duty-cycle: impact on lasing and fluorescence [6998-42]

J. Šulc, P. Černý, H. Jelínková, Czech Technical Univ. (Czech Republic);

W. Ryba-Romanowski, R. Lisiecki, P. Solarz, G. Dominiak-Dzik, Institute of Low Temperature and Structure Research (Poland); Y. Urata, Megaopto Co., Ltd. (Japan); M. Higuchi, Hokkaido Univ. (Japan)

6998 OU Record performance from a passively Q-switched Yb:Er:YVO 4 laser [6998-29]

Y. H. Tsang, C. J. Mercer, D. J. Binks, The Univ. of Manchester (United Kingdom)

\section{SESSION $5 \quad 1$ MICRON}

6998 OW Dual wavelength generation of a diode pumped Nd:GdVO4 laser at $1063 \mathrm{~nm}$ and $1066 \mathrm{~nm}$ [6998-32]

V. Kubeček, M. Drahokoupil, P. Zátorský, M. Čech, P. Hiršl, Czech Technical Univ.

(Czech Republic)

6998 OX Continuous-wave and mode-locked operation of diode-pumped Yb:NaY(WO4)2 [6998-33] A. Schmidt, S. Rivier, V. Petrov, U. Griebner, Max-Born-Institute for Nonlinear Optics and Ultrafast Spectroscopy (Germany); A. García-Cortés, M. Serrano, C. Cascales, C. Zaldo, Instituto de Ciencia de Materiales de Madrid (Spain)

$69980 Z$ Diode pumping of $\mathrm{Yb}^{3+}: \mathrm{CaGdAIO}_{4}$ [6998-35]

P. O. Petit, P. Goldner, B. Viana, Lab. de Chimie de la Matière Condensée de Paris (France); J. Boudeile, J. Didierjean, F. Balembois, F. Druon, P. Georges, Lab. Charles Fabry de l'Institut d'Optique (France) 
699812 High-pulse-energy $\mathbf{8} \mu \mathrm{m}$ laser source based on optical parametric amplification in $\mathrm{ZnGeP}_{2}$ [6998-37]

M. W. Haakestad, G. Arisholm, E. Lippert, S. Nicolas, G. Rustad, K. Stenersen, Norwegian Defense Research Establishment (Norway)

$699814 \mathrm{YAl}_{3}\left(\mathrm{BO}_{3}\right)_{4}$ : a novel NLO crystal for frequency conversion to UV wavelengths [6998-38] D. Rytz, A. Gross, S. Vernay, V. Wesemann, F.E.E. GmbH (Germany)

699815 Laser damage investigation in nonlinear crystals: study of $\mathrm{KTiOPO}_{4}$ (KTP) and RbTiOPO 4 (RTP) crystals [6998-40]

A. Hildenbrand, F. R. Wagner, J.-Y. Natoli, M. Commandré, Institut Fresnel, Univ. Aix Marseille (France); H. Albrecht, F. Théodore, Cristal Laser S.A. (France)

699816 Efficient diode-pumped intracavity frequency-doubled CW Nd: YLF laser emitting at 656nm for a silver atom optical clock [6998-62] J.-P. Loisel, S. Topcu, L. Chassagne, Y. Alayli, Univ. of Versailles (France); P. R. Dahoo, SA (France); T. Badr, P. Juncar, LNE-INM/CNAM (France)

POSTER SESSION

699817 Diode pumped Er:YVO 4 microchip laser [6998-28]

H. Jelínková, J. Šulc, Czech Technical Univ. (Czech Republic); W. Ryba-Romanowski, Institute of Low Temperature and Structure Research (Poland); T. Lukasiewicz, Institute of Electronic Materials Technology (Poland)

699818 Gain variation of Raman amplifier in silicon micro-ring coupled-resonator optical waveguides [6998-41] E. Daghigh Ahmadi, Shahid Bahonar Univ. of Kerman (Iran); F. Farman, Sharif Univ. of Technology (Iran); R. Taghiabadi, Shahid Bahonar Univ. of Kerman (Iran); S. Keyvaninia, Sharif Univ. of Technology (Iran); A. Bahrampour, Sharif Univ. of Technology (Iran) and Shahid Bahonar Univ. of Kerman (Iran)

699819 Nd:YAG laser systems with radiation delivery by thin hollow waveguides [6998-43] M. Nĕmec, H. Jelínková, J. Šulc, Czech Technical Univ. (Czech Republic); M. Miyagi, K. Iwai, Sendai National College of Technology (Japan); Y.-W. Shi, Fudan Univ. (China); Y. Matsuura, Tohoku Univ. (Japan)

6998 1A Optical and laser characterization of 2\% Nd:YAG ceramics elements [6998-44] Z. Librant, H. Węglarz, A. Wajler, H. Tomaszewski, T. Łukasiewicz, Institute of Electronic Materials Technology (Poland); J. K. Jabczyński, W. Zendzian, J. Kwiatkowski, Military Univ. of Technology (Poland)

6998 1B The study of spectroscopic and luminescence properties of disordered laser crystals calcium niobium gallium garnet doped with $\mathrm{Er}^{3+}$ [6998-45]

P. A. Ryabochkina, Mordovian State Univ. (Russia); Y. K. Voronko, General Physics Institute (Russia); A. V. Malov, Mordovian State Univ. (Russia); M. O. Marychev, N.I. Lobachevsky State Univ. of Nizhni Novgorod (Russia); A. A. Sobol, S. N. Ushakov, General Physics Institute (Russia); E. V. Chuprunov, N.I. Lobachevsky State Univ. of Nizhni Novgorod (Russia) 
6998 1C Investigations on fibers for high-peak power pulsed Nd:YAG-lasers for laser detonator [6998-46]

Y. Gao, X. Zhao, W. Su, Y. Cheng, M. Xu, W. Duan, H. Yu, China Academy of Engineering Physics (China)

6998 1D Optimized single amplified ultra-short laser pulse [6998-47]

J. Chen, K.-C. Chuang, Chung-Hua Univ. (Taiwan)

6998 1E Laser induced fluorescence as a tool for the study of laser damage precursors in transparent materials [6998-48]

A. Ciapponi, S. Palmier, F. Wagner, J.-Y. Natoli, Institut Fresnel, Univ. de Méditerranée (France); H. Piombini, D. Damiani, B. Bertussi, CEA-Le Ripault (France)

6998 IF 300-kW, eye-safe intracavity OPO with efficient pulse shortening [6998-49] W. Zendzian, J. K. Jabczynski, J. Kwiatkowski, Military Univ. of Technology (Poland)

$69981 \mathrm{H} \quad$ Characterization and optimization of a miniature 2.94 $\mu \mathrm{m}$ Er:YAG laser [6998-51] C. Yu, R.-B. Jhang, National Central Univ. (Taiwan); E.-Y. Pan, National Defense Univ. (Taiwan); H.-F. Yau, National Central Univ. (Taiwan); Y.-P. Tong, DailyCare Biomedical, Inc. (Taiwan)

$699811 \quad$ A Q-switched Nd:YCOB laser [6998-52]

C. J. Mercer, Y. H. Tsang, D. J. Binks, The Univ. of Manchester (United Kingdom); H. Zhang, J. Wang, Shandong Univ. (China)

$69981 \mathrm{~J} \quad$ Fictive temperature dependences of optical properties in Yb-doped silica glass [6998-53] K. Saito, R. Yamamoto, N. Kamiya, E. H. Sekiya, P. Barua, Toyota Technological Institute (Japan)

6998 1K Gain flattened fiber Raman amplifiers by tailoring Raman amplification bandwidth of tellurite glasses [6998-54]

R. Jose, G. Qin, Y. Arai, T. Suzuki, Y. Ohishi, Toyota Technological Institute (Japan)

$69981 \mathrm{~N} \mathrm{Z-scan} \mathrm{measurements} \mathrm{of} \mathrm{nonlinear} \mathrm{refractive} \mathrm{indices} \mathrm{of} \mathrm{NaT}\left(\mathrm{XO}_{4}\right)_{2} \mathrm{~T}=\mathrm{Y}, \mathrm{La}, \mathrm{Gd}, \mathrm{LU}$ and $\mathrm{Bi}$, $\mathrm{X}=$ Mo, W, femtosecond laser crystals [6998-57]

A. García-Cortés, M.-D. Serrano, C. Zaldo, C. Cascales, Instituto de Ciencia de Materiales de Madrid (Spain); G. Strömqvist, V. Pasiskevicius, KTH Royal Institute of Technology (Sweden)

$69981 \mathrm{~A}$ A mechanically Q-switched Yb:Er:YVO4 laser [6998-60]

Y. H. Tsang, C. J. Mercer, D. J. Binks, The Univ. of Manchester (United Kingdom)

6998 IR An inhomogeneous theoretical model for analyzing the temporal response of high concentration erbium-doped fiber lasers [6998-63]

S. Keyvaninia, M. Karvar, Sharif Univ. of Technology (Iran) and International Ctr. of Science, High Technology and Environmental Science (Iran); A. Bahrampour, Sharif Univ. of Technology (Iran), International Ctr. of Science, High Technology and Environmental Science (Iran), and Vali-Asr Univ. of Rafsanjan (Iran) 
6998 is Passively mode-locked waveguide lasers using carbon nanotube saturable absorber [6998-64]

H. Chen, Yangtze Univ. (China); Q. Wang, College of Optical Sciences, Univ. of Arizona (USA)

6998 IT Numerical rate equation modelling of a $1.61 \mu \mathrm{m}$ pumped $\sim 2 \mu \mathrm{m} \mathrm{Tm}^{3+}$-doped tellurite fibre laser [6998-65]

B. D. O. Richards, C. A. Evans, Z. Ikonić, P. Harrison, The Univ. of Leeds (United Kingdom); Y. H. Tsang, D. J. Binks, The Univ. of Manchester (United Kingdom); J. Lousteau, A. Jha, The Univ. of Leeds (United Kingdom)

$69981 \mathrm{U}$ Thermal and optical properties of new fluorotellurite glasses for photonics application [6998-66]

G. Liao, Q. Chen, J. Xing, D. Milanese, M. Fokine, M. Ferraris, Politecnico di Torino (Italy)

Author Index 


\title{
Conference Committee
}

\author{
Symposium Chairs
}

Hugo Thienpont, Vrije Universiteit Brussel (Belgium)

Patrick P. Meyrueis, Université Louis Pasteur (France)

Giancarlo C. Righini, Istituto di Fisica Applicata Nello Carrara, CNR (Italy)

\section{Conference Chairs}

Jonathan A. Terry, University of St. Andrews (United Kingdom)

Thomas Graf, Universität Stuttgart (Germany)

Helena Jelínková, Czech Technical University in Prague

(Czech Republic)

Program Committee

Arnaud Brignon, Thales Research and Technology (France)

Timothy J. Carrig, Lockheed Martin Coherent Technologies (USA)

Giulio Cerullo, Politecnico di Milano (Italy)

Efstratios Georgiou, Technological Education Institute-Crete (Greece)

Nikolay V. Kuleshov, International Laser Center (Belarus)

Valdas Pasiskevicius, Royal Institute of Technology (Sweden)

Gunnar Rustad, Norwegian Defense Research Establishment (Norway)

Alphan Sennaroglu, Koç University (Turkey)

Yehoshua Shimony, Soreq Nuclear Research Center (Israel)

Session Chairs

1 Fibre Lasers

Thomas Graf, Universität Stuttgart (Germany)

2 Pulsed SSL

Helena Jelínková, Czech Technical University (Czech Republic)

3 Beam Control and Transmission

Jonathan A. Terry, University of St. Andrews (United Kingdom)

$4 \quad$ Infrared Lasers

Jonathan A. Terry, University of St. Andrews (United Kingdom)

51 Micron

Efstratios Georgiou, Technological Education Institute-Crete (Greece) 
Yehoshua Shimony, Soreq Nuclear Research Center (Israel) 


\section{Introduction}

This was the third occurrence of the Solid State Lasers and Amplifiers conference, held as part of the Photonics Europe symposium, over the period 8-10 April 2008 in Strasbourg, France. The participation level increased compared to 2 years ago, reflected by the conference extending over 3 days, with 37 oral papers and an interactive poster session of some 22 papers.

Particular hot topics for this year were fibre lasers, with two invited papers, from Shibin Jiang of NP Photonics and Stuart Jackson of the University of Sydney, and a new session entitled Beam Control and Transmission, regarding spatial and polarisation analysis and control of beams, and beam delivery systems to actually get the generated beams to their respective applications. Pulsed solid state lasers was again a session topic, regarding both Q-switching and mode-locking, the latter being implemented with Quantum Dot structures in an invited paper from Edik Rafailov of the University of Dundee, as was Infrared Lasers, including Raman conversion in Tungstates and Dy doped in Lead Thiogallate as a direct source for $>4 \mu \mathrm{m}$, as described in an invited paper by Maxim Doroshenko of the General Physics Institute (Moscow). Despite the long history, there is always something new concerning 1 Micron lasers, often with new host materials, but also in scaling to high powers with excellent beam quality and spectral purity, as described by Dietmar Kracht of the Laser Zentrum Hanover, where the application was gravitational wave detection. The final oral session was on Non-linear Optical sources, kicked-off by a presentation on the advantages of periodic and quasi-periodic nonlinear photonic crystals from Ady Arie of Tel-Aviv University.

A new addition this year was a keynote presentation, from John Collier of the UK Science and Technology Facilities Council, giving a flavour of what might be expected of the upcoming large-scale project HiPER, described as the European path to laser fusion and related plasma science.

This proceedings volume provides more detail on all the presented papers for which a manuscript was submitted.

Jonathan A. Terry

Thomas Graf

Helena Jelínková 
Downloaded From: https://www.spiedigitallibrary.org/conference-proceedings-of-spie on 26 Apr 2023

Terms of Use: https://www.spiedigitallibrary.org/terms-of-use 